\title{
Gambaran Klinis dan Laboratoris Diabetes Mellitus tipe-1 pada Anak Saat Pertama Kali Datang ke Bagian IKA-RSCM Jakarta
}

\author{
Aman B Pulungan, Riza Mansyoer, Jose RL Batubara, Bambang Tridjaja AAP
}

\begin{abstract}
Diabetes Mellitus tipe-1 merupakan salah satu penyakit kronis yang sampai saat ini belum dapat disembuhkan. Walaupun demikian, berkat kemajuan teknologi kedokteran kualitas hidup pasien DM tipe-1 dapat terpelihara. Sebagian besar kasus DM pada anak termasuk di dalam DM tipe-1, namun sedikit sekali tulisan di Indonesia mengenai karakteristik klinis dan laboratorium DM tipe-1. Hal ini mengakibatkan banyak tenaga medis yang tidak mengetahuinya sehingga sering sekali salah dalam mendiagnosis pasien DM tipe-1. Pasien DM tipe-1 sebagian besar mempunyai riwayat perjalanan klinis, dengan poliuria, polidipsia, polifagia, dan berat badan yang cepat menurun. Untuk mengurangi keterlambatan diagnosis maka kewaspadaan terhadap DM tipe-1 merupakan kata kunci. Telah dilakukan penelitian deskriptif retrospektif pada semua pasien DM tipe-1 yang berobat ke Bagian IKA-RSCM antara tahun 1989-1999. Seluruh subyek penelitian diambil dari catatan medis dan didapat 41 kasus dengan DM tipe-1 dengan sebagian besar anak perempuan. Usia terbanyak saat datang pertama kali ke Bagian IKA-RSCM pada usia 5-10 tahun (56\%). Dari 41 kasus DM tipe-1, hanya 31\% yang mempunyai keturunan keluarga DM. Saat datang ke Bagian IKA-RSCM 66\% dengan katoasidasis diabetik, $71 \%$ menderita gizi kurang dan seluruh pasien datang dengan keluhan poliuria, polidipsia, polifagia dan adanya penurunan berat badan yang progresif. Gangguan kesadaran juga menyertai pasien dengan KAD. Kadar gula darah pasien DM tipe-1 terbanyak antara $300-500 \mathrm{mg} / \mathrm{dl}(51 \%)$. Semua pasien pada saat awal diagnosis kadar HbA1c di atas normal dan C-peptida di bawah normal.
\end{abstract}

Kata kunci: DM tipe-1, poliuria, polidipsia, polifagia, ketoasidosis diabetik.

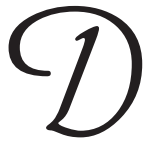

iabetes mellitus (DM) adalah kelainan yang bersifat kronis ditandai dengan gangguan metabolisme karbohidrat, protein dan lemak yang disebabkan defisiensi insulin baik absolut dan atau relatif. ${ }^{1}$ Defisiensi insulin absolut biasanya didapatkan pada pasien diabetes mellitus tipe-1. Hal ini disebabkan adanya kerusakan sel $b$ pankreas yang progresif sehingga insulin tidak dapat disintesis oleh kelenjar pankreas. Defisiensi insulin relatif ditemukan pada pasien

Alamat korespondensi:

Dr. Aman B Pulungan, Sp.A(K).

Staf Subbagian Endokrinologi. Bagian Ilmu Kesehatan Anak FKUIRSCM. Jl. Salemba no. 6, Jakarta 10430.

Telepon: 021-3100669. Fax.021-390 7743.
DM tipe-2 oleh karena pemakaian insulin di dalam tubuh kurang efektif. ${ }^{2}$ Sebagian besar kasus DM pada anak termasuk dalam DM tipe-1, yang terjadi akibat suatu proses autoimun yang merusak sel b pankreas sehingga produksi insulin berkurang bahkan berhenti. Oleh karena itu pasien sangat tergantung pada insulin untuk kelangsungan hidupnya. Diabetes mellitus tipe-1 ini disebut juga DM tergantung insulin (DMTI).

Klasifikasi DM berdasarkan etiologi mempunyai 4 bentuk klinis yaitu DM tipe-1, DM tipe 2, DM tipe lain dan gestational diabetes mellitus. DM tipe-1 merupakan tipe DM terbanyak pada anak dan didapatkan di berbagai negara termasuk Indonesia. Karakteristik DM tipe-1 mempunyai kadar insulin endogen yang rendah sehingga pasien sangat tergantung 
pada insulin eksogen. ${ }^{1}$ Data dari Bagian Ilmu Kesehatan Anak Fakultas Kedokteran Universitas Indonesia RS Cipto Mangunkusumo (IKA FKUI-RSCM) dari tahun 1973-1988 didapatkan 28 pasien DM tipe-1 dengan usia terbanyak 6-10 tahun, anak perempuan mempunyai proporsi 3 kali lebih banyak dari anak lelaki. ${ }^{3}$

Sampai saat ini melalui penelusuran kepustakaan sedikit sekali tulisan di Indonesia mengenai karakteristik klinis dan laboratorium DM tipe-1. Hal ini mengakibatkan banyak tenaga medis yang tidak mengetahuinya sehingga sering sekali salah dalam mendiagnosis pasien DM tipe-1. Gambaran klinis yang khas pada DM tipe-1 berupa poliuria, polidipsi, polifagia dan adanya penurunan berat badan yang progresif sering terlupakan. Dengan demikian tindakan yang diberikan pada pasien tersebut tidak adekuat, sehingga pasien tersebut mengalami hiperglikemi kronis dan akhirnya jatuh dalam komplikasi yang berat seperti ketoasidosis diabetik (KAD), gangguan pertumbuhan dan komplikasi kronis lainnya berupa retinopati diebetika, nefropati diabetika, neuropati diabetika dan sebagainya. ${ }^{4,5}$ Selain itu masyarakat masih banyak yang kurang percaya ada DM pada anak, barulah setelah anaknya dirawat dengan komplikasi akut seperti KAD mereka menyadarinya. Gambaran klinis yang tidak khas perlu diperhatikan dan ditelusuri lebih lanjut untuk lebih menajamkan diagnosis seperti cepat lelah, kesemutan atau kejang otot kaki. Gangguan kesadaran dan asidosis metabolik selalu bermanifestasi bila pasien datang dengan komplikasi KAD.4Pemeriksaan laboratorium darah perlu dikerjakan untuk menegakkan diagnosis pasti DM tipe-1. Pemeriksaan kadar gula darah, darah perifer lengkap, HbA1c, C-peptida, dan bila pasien menderita KAD diperiksa juga analisis gas darah, ureum dan kreatinin, serta elektrolit darah. ${ }^{4}$

Penelitian ini bertujuan untuk mengetahui gambaran klinis dan laboratorium DM tipe-1 pada anak saat pertama kali datang ke Bagian IKA-RSCM. Dengan penelitian ini data yang tersajikan dapat dipakai oleh tenaga medis yang bekerja di klinik terdepan pelayanan kesehatan dalam mendiagnosis dan menatalaksana DM tipe-1 dengan baik.

\section{Metoda Penelitian}

Penelitian ini bersifat deskriptif retrospektif. Subyek adalah semua pasien DM tipe-1 yang berobat ke Bagian IKA-RSCM antara tahun 1989-1999.

\section{Hasil Penelitian}

Seluruh subyek penelitian antara tahun 1989-1999 berjumlah 41 catatan medis pasien DM tipe-1 dengan 16 anak lelaki dan 25 anak perempuan. Saat diagnosis DM tipe-1 ditegakkan (saat datang ke Bagian IKARSCM) terbanyak pada kelompok usia 5-10 tahun yaitu 23 kasus (56\%) (gambar 1)

Dari 41 kasus DM tipe-1, 31\% mempunyai riwayat keturunan keluarga DM dan 69\% tidak mempunyai riwayat keturunan keluarga DM. Saat datang ke Bagian IKA-RSCM 66\% dengan KAD, 20\% pasca KAD (pasien menderita KAD bukan di RSCM), dan $14 \%$ tidak menderita KAD. Tujuh puluh satu persen menderita gizi kurang dan 29\% dengan gizi baik (Gambar 1, 2, 3 dan 4).

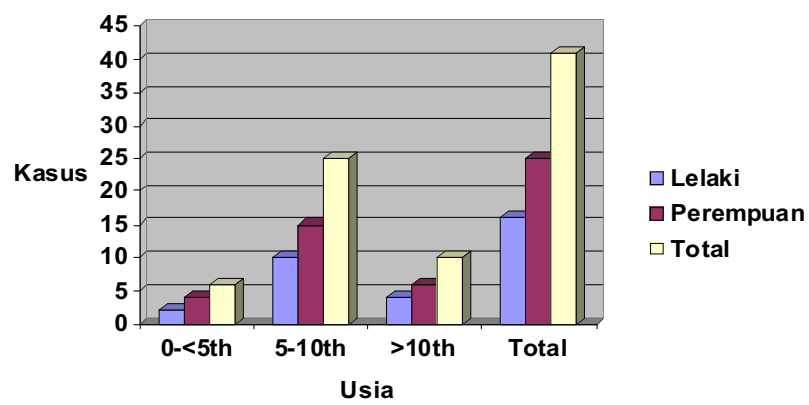

Gambar 1. Sebaran umur pasien saat diagnosis DMTI

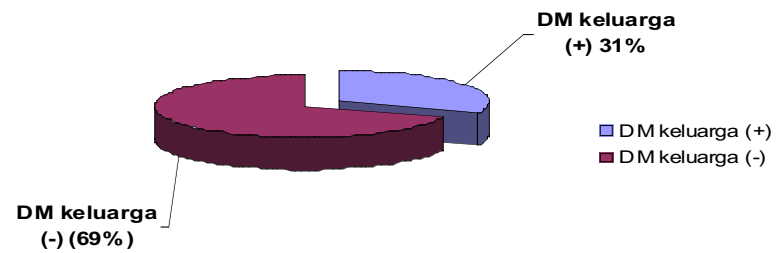

Gambar 2. Sebaran adanya riwayat DM dalam keluarga pada 41 pasien DM tipe-1

Sebaran pasien

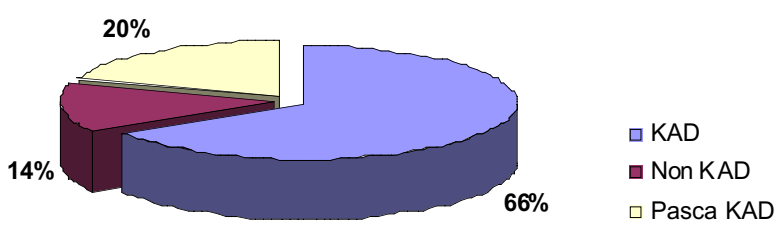

Gambar 3. Sebaran keadaan 41 pasien saat datang ke bagian IKA-RSCM 
$29 \%$

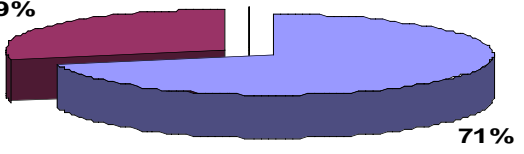

Gambar 4. Sebaran status gizi 41 pasien DM tipe -1

Seluruh pasien DM tipe-1 datang dengan keluhan poliuria, polidipsi, polifagia dan adanya penurunan berat badan progresif. Gangguan kesadaran dan asidosis metabolik menyertai pasien dengan KAD. Sedangkan sebagian kecil disertai dengan cepat lelah/lemah (Gambar 5)

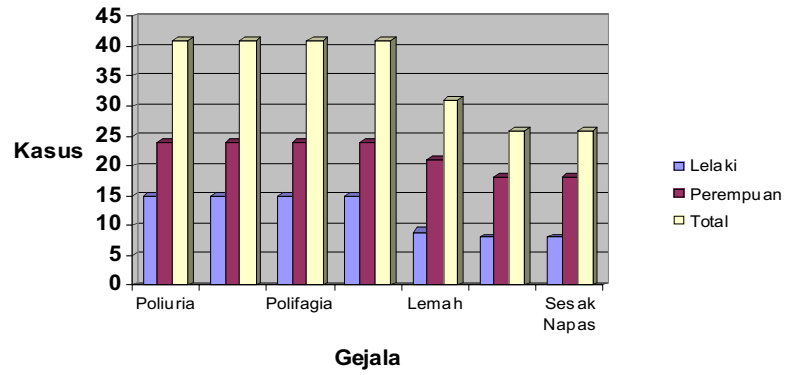

Gambar 5. Gejala klinis 41 pasien DM tipe-1

Kadar gula darah pasien DM tipe-1 saat datang pertama kali ke Bagian IKA-RSCM (Gambar 6) terbanyak antara $300-500 \mathrm{mg} / \mathrm{dl}$ (51 kasus), lebih dari $500 \mathrm{mg} / \mathrm{dl}$ (37 kasus), antara $200-300 \mathrm{mg} / \mathrm{dl}$ sebanyak 12 kasus. Terhadap kadar kolesterol, HbA1c dan Cpeptida dipergunakan kadar median karena distribusi ke-5 variabel ini tidak normal. Tabel 1 memperlihatkan rentang dan median pemeriksaan kadar kolesterol, HbA1c dan C-peptida.

\section{Pembahasan}

Penelitian ini menggunakan desain deskriptif

Tabel 1. Sebaran median kadar kolesterol,HbA1c dan Cpeptida pasien DM tipe-1

\begin{tabular}{lll}
\hline Serum & Median & Rentang \\
\hline Kolesterol $(\mathrm{mg} / \mathrm{dl})$ & 186 & $115-253$ \\
HbA1c $(\%)$ & 10,6 & $7,0-17,0$ \\
C-pept $(\mathrm{ng} / \mathrm{ml})$ & $<0,5$ & $<0,5-0,6$ \\
\hline
\end{tabular}

Jumlah kasus $=24$

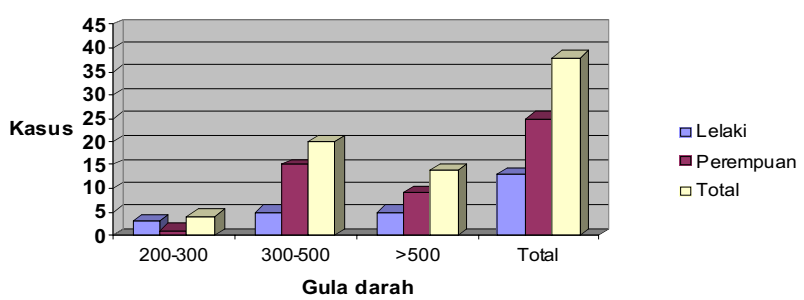

Gambar 6. Kadar gula darah pasien DM tipe-1

retrospektif untuk mengetahui gambaran klinis dan laboratorium DM tipe-1 pada anak saat datang pertama kali ke Bagian IKA-RSCM. Dengan desain seperti ini kami menyadari adanya keterbatasan yaitu tidak dapat diambil kesimpulan yang pasti adanya hubungan variabel yang diteliti dengan terjadinya DM tipe-1.

\section{Riwayat DM keluarga, umur dan jenis kelamin}

Dalam kurun waktu antara tahun 1989-1999 terdapat 41 pasien DM tipe-1 yang terdiri dari 16 anak lelaki (39\%) dan 25 anak perempuan (61\%) dengan 6 pasien berusia kurang dari 5 tahun, 23 pasien usia 510 tahun dan 12 pasien usia lebih dari 10 tahun. Proporsi anak perempuan hampir 2 kali lebih banyak dari anak lelaki dan usia terbanyak terdapat antara 510 tahun. Hal ini sesuai dengan penelitian Assin dkk bahwa anak perempuan lebih banyak dari anak lelaki dengan usia terbanyak 6-10 tahun. ${ }^{3}$ Di Amerika Serikat angka kejadian terbanyak pada rentang usia 9-12 tahun dan anak perempuan dua kali lebih banyak dari anak lelaki. ${ }^{6}$ Pada penelitian ini didapat riwayat DM keluarga pada $31 \%$ pasien. Faktor genetik dan lingkungan sangat berperan pada terjadinya DM tipe-1. Dari kepustakaan dikemukakan walaupun hampir $80 \%$ kasus DM tipe1 baru tidak mempunyai riwayat keluarga dengan penyakit serupa, faktor genetik diakui berperan dalam patogenesis DM tipe-1. Faktor genetik dikaitkan dengan pola HLA tertentu, tetapi sistem HLA bukan merupakan satu-satunya faktor susceptibility gene atau faktor kerentanan. Diperlukan suatu faktor yang berasal dari lingkungan seperti infeksi virus, toksin, untuk memicu gejala klinis DM tipe-1 yang rentan. Namun didapatkan bahwa gen HLA yang berkaitan dengan kejadian DM lebih sering ditemukan pada pasien yang terdiagnosis saat dewasa. ${ }^{7,8}$ 


\section{Gambaran klinis dan laboratoris}

\section{Gambaran klinis}

Dari gambaran klinis terlihat bahwa poliuria, polidipsi, polifagia dan penurunan berat badan terjadi pada seluruh pasien DM tipe-1. Hal ini sesuai dengan kepustakaan bahwa ke empat gejala klinis ini hampir terjadi pada seluruh pasien DM tipe-1. 4,6 Gejala klinis lain cepat lelah pada $30(75,6 \%)$ kasus. Dibanding dewasa, DM pada anak mempunyai gambaran klinis yang lebih akut, lebih berat dan tergantung insulin.

Defisiensi insulin pada DM tipe-1 akan mengurangi ambilan glukosa oleh otot, jaringan lunak, jaringan splanikus dan akan terjadi peningkatan glikogenolisis dan glukoneogenesis. Kadar gula darah akan meningkat dan mengakibatkan peningkatan osmolalitas cairan ekstra selular. Peningkatan osmolalitas yang melebihi ambang batas ginjal akan menyebabkan glukosa dikeluarkan melalui urin. Glukosa yang ada akan menarik air dan elektrolit lain sehingga pasien mengeluh sering kencing atau poliuria. Dengan demikian tubuh akan selalu dalam keadaan haus dan mengakibatkan banyak minum (polidipsia). ${ }^{4,6}$ Polifagia disebabkan glukosa di dalam darah tidak dapat dipakai pada jaringan-jaringan perifer sehingga tubuh akan kekurangan glukosa (proses kelaparan starvation) yang menyebabkan pasien banyak makan. Selain itu defisiensi insulin pada pasien DM tipe-1 juga mengakibatkan berkurangnya ambilan asam amino dan sintesis protein, sehingga pemenuhan nitrogen otot kurang. Katabolisme protein juga meningkat, sehingga secara klinis massa otot dijaringan perifer berkurang mengakibatkan penurunan berat badan. Glukosa yang tidak terpakai di sel atau jaringan perifer mengakibatkan tubuh akan lemah dan kurang aktivitas. ${ }^{4}$ Pada keadaan seluruh kasus KAD 27 kasus mempunyai gejala sesak nafas dan penurunan kesadaran. Hal ini sesuai dengan kepustakaan bahwa pada keadaan KAD selalu bermanisfestasi adanya penurunan kesadaran dan asidosis metabolik. Pasien pada umumnya datang dengan ketoasidosis karena keterlambatan diagnosis.

\section{Gambaran laboratoris}

Hiperglikemia dijumpai pada seluruh pasien DM tipe-1. Kadar glukosa darah terbanyak dijumpai antara 300-500 mg/dl pada 21 kasus (51,2\%), lebih dari $500 \mathrm{mg} / \mathrm{dl}$ pada $15(36,5 \%)$ kasus dan antara 200-300 mg/dl pada 5 (12,3\%) kasus. Diagnosis DM sudah dapat ditegakkan bila memenuhi salah satu kriteria, yaitu bila ditemukan gejala klinis poliuria, polidipsia, polifagia, berat badan menurun, dan kadar glukosa darah sewaktu lebih dari 200 mg/ $\mathrm{dl}$; atau bila asimptomatis, maka kadar glukosa darah sewaktu harus lebih $200 \mathrm{mg} / \mathrm{dl}$ atau kadar gula darah puasa lebih tinggi dari normal atau dengan tes toleransi glukosa kadar glukosa darah puasa $>140 \mathrm{mg} / \mathrm{dl}$.9 Untuk menilai sebaran kadar, kolesterol, HbA1c, dan C-peptida dipergunakan kadar median karena distribusi ketiga variable ini tidak normal.

Kadar hemoglobin glikosilat (HbA1c) pasien DM tipe-1 yang diperiksa hanya 24 pasien dengan semua kasus di atas nilai normal (normal 4,5-6,3), rentang penelitian ini 7,0-17,0 \%. Hasil ini sesuai dengan perjalanan DM tipe-1 yang mana pada awal diagnosis kadar HbA1c seharusnya di atas normal. ${ }^{6-8} \mathrm{HbAlc}$ akan meningkat bila telah terjadi proses glikosilasi non enzimatik dari hemoglobin. Proses ini mempunyai dua fase yaitu fase awal dan fase lanjut. Pada fase awal glukosa bereaksi dengan protein membentuk basa yang kemudian membentuk aldimin. Reaksi ini bersifat reversibel. Pada fase lanjut glikosilasi non enzim terjadi pada tingkat jaringan. Reaksi ini bersifat ireversibel sehingga nilai tidak berkurang meskipun kadar glukosa darah menjadi normal. ${ }^{6,910 .}$

Sebaran median kadar kolesterol pada penelitian ini adalah $186 \mathrm{mg} / \mathrm{dl}$ (rentang $115-253 \mathrm{mg} / \mathrm{dl}$ ). Nilai normal kadar kolesteol adalah $<200 \mathrm{mg} / \mathrm{dl}$. Pada pasien DM tipe-1 dilaporkan adanya perbedaan kadar kolesterol pada pasien pubertas dan pasien prapubertas. Kadar kolesterol biasanya lebih tinggi pada pasien DM tipe-1 selama masa pubertas. ${ }^{9}$ Pada penelitian ini walaupun kelompok umur pasien terbanyak pada kelompok umur 5-10 tahun, namun hasil kadar kolesterol ini tidak dapat dihubungkan dengan umur, karena tidak semua pasien diperiksa kadar kolesterolnya pada awal diagnosis.

Sebaran median kadar C-peptida adalah $<0,5 \mathrm{ng} /$ $\mathrm{ml}$ (nilai normal 0,9-4ng/ml). Pada penelitian ini tidak ada pasien dengan C-peptida yang normal. Hal ini sesuai dengan awal perjalanan penyakit DM tipe-1, insulin tidak akan atau sedikit sekali diproduksi, sehingga C-peptida juga tidak ada atau sedikit dalam sirkulasi. ${ }^{9}$ 


\section{Kesimpulan}

Semua pasien DM tipe-1 anak yang datang pertama kali ke Bagian IKA-RSCM mempunyai gejala klinis poliuria, polidipsi, polifagia dan penurunan berat badan. Usia terbanyak terdapat antara 5-10 tahun dan proporsi anak perempuan lebih banyak dari pada anak laki-laki. Kurang dari separuhnya mempunyai riwayat DM dalam keluarga. Hampir dua pertiga pasien datang dengan $\mathrm{KAD}$, gizi kurang dan kadar gula darah lebih dari $300 \mathrm{mg} / \mathrm{dl}$. Semua pasien kadar HbAlc di atas nilai normal dan C-peptida di bawah nilai normal.

\section{Daftar Pustaka}

1. World Health Organization. Prevention of diabetes millitus. WHO Tech Rep Ser, Geneva:1994.

2. Andi Wijaya. Pemeriksaan laboratorium untuk diagnosis dan pengelolaan diabetes militus. Prodia Diagnostic Educational Services 1997; 1:1-16.

3. Sutan Assin M, Rukman Y, Batubara JR.Childhood onset of diabetes mellitus report on hospital cases. Pediatrik Indonesia 1990; 30:209-12.
4. Arslanian S, Becker D, Drash A. Diabetes mellitus in the child and adolescents. Dalam: Kappy MS. Blizzard RM, Migeon CJ, penyunting. The diagnosis and treatment of endocrine disorders in childhood and adolescence; edisi ke-4. Illinois:Charles C.Thomas, 1994; 9611024.

5. Hershman JM. Dalam: Alexander Mandle, Priscila Whate, Penyunting. Diabetes mellitus. Joslin S Endocrine pathophysiology a patient oriented approach. Philadelphia: Lea and Febiger, 1977; 207-43.

6. Travis LB, Brouhard BH,Schreneir BJ. The Clinical Disease. Dalam: Travis LB, Brouhard BH,Schreneir BJ. Penyunting. Diabetes mellitus in children and adolescents. Philadelphia: WB Saunders Company,1987; 1872 .

7. Tridjaya B, Batubara J.R., penyunting. Konsensus nasional pengelolaan diabetes mellitus tipe-1 di Indonesia. UKK Endokrinologi IDAI. Jakarta 2000.

8. Komulainen J, Kulmala P, Savola K. Clinical autoimmune, and genetic characteristic of very young children with type 1 diabetes. Diabetes care 1999; 22:1950-4.

9. Goldstein DE, Parker M, England JD dkk.Clinical application of glycosilated hemoglobon measurements. Diabetes 1982; 31:70-8.

10. Nathan DM, MC Kitrick C, Larkin M dkk. Gltcemic control in diabetes mellitus: have changes in therapy made a difference. Am J Med 1996; 100:157-63. 